\title{
Immunoproteomics approach for fragment based vaccine design from Coxsackie B virus
}

\section{Gomase V.S. and Shyamkumar K.}

*Proteomics Unit, Department of Bioinformatics, Padmashree Dr. D. Y. Patil University, Plot No-50, Sector-15, CBD Belapur, Navi Mumbai, 400614, MS, India, Mobile- +91-99877770696, Mailvirusgene1@yahoo.co.in

\begin{abstract}
Coxsackieviruses are non-enveloped viruses with linear single-stranded RNA. Group B coxsackieviruses were noted to cause a spastic paralysis due to focal muscle injury and degeneration of neuronal tissue. Peptide fragments of Coxsackievirus-B coat protein can be used to select nonamers for use in rational vaccine design and to increase the understanding of roles of the immune system in infectious diseases. Analysis shows MHC class II binding peptides of coat protein from Coxsackievirus-B are important determinant for protection of host form viral infection. In this assay we predicted the binding affinity of coat protein having 281 amino acids, which shows 273 nonamers. These peptides are from a set of aligned peptides known to bind to a given $\mathrm{MHC}$ molecule as the predictor of MHC-peptide binding. MHCll molecules bind peptides in similar yet different modes and alignments of MHCll-ligands were obtained to be consistent with the binding mode of the peptides to their MHC class, this means the increase in affinity of MHC binding peptides may result in enhancement of immunogenicity of coat protein nonamers. Binding ability prediction of antigen peptides to major histocompatibility complex (MHC) class I \& II molecules is important in vaccine development from Coxsackievirus.
\end{abstract}

Key words: Antigen, Epitope, PSSM, SVM, MHC, Peptide vaccine

Abbreviations: Goldman, Engelberg and Steitz, (GES); major histocompatibility complex, (MHC); Position Specific Scoring Matrices, (PSSMs); Support Vector Machine, (SVM)

\section{Introduction}

Coxsackieviruses belong to the family Picornaviridae and the genus Enterovirus, which also includes poliovirus and echovirus. Enteroviruses are among the most common and important human pathogens. Coxsackie B viruses are single-strand positive-sense RNA viruses that are resistant to a wide variety of chemical treatments. The viral particles themselves are roughly $30 \mathrm{~nm}$ icosahedrons [1]. The virus is most frequently distributed via the fecal-oral route, and infection commonly occurs after eating contaminated food. Coxsackie B viruses are cytolytic, and Coxsackie B2 and B5 viruses have been implicated in hand, foot and mouth disease as well as respiratory infection [2]. Infection in infants is mostly asymptomatic, but sometimes results in the death of the infant, often due to myocarditis [3]. Birth defects may also be present in a Coxsackie B infected infant. Coxsackieviruses are transmitted primarily via the fecal-oral route and respiratory aerosols, although transmission via fomites is possible. The viruses initially replicate in the upper respiratory tract and the distal small bowel. They have been found in the respiratory tract up to 3 weeks after initial infection and in feces up to 8 weeks after initial infection. The viruses have been found to replicate in the submucosal lymph tissue and disseminate to the reticuloendothelial system. Further dissemination to target organs occurs following a secondary viremia.

\section{Methodology}

In this research work antigenic epitopes of coat protein from Coxsackie $B$ virus is determined using the Gomase in 2007, Hopp and Woods, Welling, Parker and Protrusion Index (Thornton) antigenicity [4-6]. The major histocompatibility complex (MHC) peptide binding of coat protein is predicted using neural networks trained on $C$ terminals of known epitopes. In analysis predicted $\mathrm{MHC} /$ peptide binding of coat protein is a logtransformed value related to the IC50 values in $\mathrm{nM}$ units. MHC2Pred predicts peptide binders to $\mathrm{MHCl}$ and $\mathrm{MHCll}$ molecules from protein sequences or sequence alignments using Position Specific Scoring Matrices (PSSMs). Support Vector Machine (SVM) based method for prediction of promiscuous MHC class II binding peptides. SVM has been trained on the binary input of single amino acid sequence [611]. In addition, we predict those MHC ligands from whose C-terminal end is likely to be the result of proteosomal cleavage [12]. 


\section{Results and Interpretations}

We found binding of peptides to a number of different alleles using Position Specific Scoring Matrix. A coat protein sequence is 281 residues long, having antigenic $\mathrm{MHC}$ binding peptides. MHC molecules are cell surface glycoproteins, which take active part in host immune reactions and involvement of $\mathrm{MHC}$ class-I and MHC II in response to almost all antigens. PSSM based server predict the peptide binders to $\mathrm{MHCl}$ molecules of coat protein sequence are as 11 mer_H2 $\mathrm{Db}$, 10 mer_H2_Db, 9mer_H2_Db, 8mer_H2_Db and also peptide binders to MHCII molecules of coat protein sequence as I_Ab.p, I_Ad.p, analysis found antigenic epitopes region in putative coat protein (Table 1). We also found the SVM based MHCII-IAb peptide regions; MHCII-IAd peptide regions; MHCII-IAg7 peptide regions and MHCll- RT1.B peptide regions, which represented predicted binders from viral coat protein (Table 2). The predicted binding affinity is normalized by the $1 \%$ fractil. We describe an improved method for predicting linear epitopes (Table 2). The region of maximal hydrophilicity is likely to be an antigenic site, having hydrophobic characteristics, because terminal regions of coat protein is solvent accessible and unstructured, antibodies against those regions are also likely to recognize the native protein. It was shown that a coat protein is hydrophobic in nature and contains segments of low complexity and high-predicted flexibility. Predicted antigenic fragments can bind to MHC molecule is the first bottlenecks in vaccine design.

\section{Conclusion}

A coat protein from Coxsackie $B$ virus peptide nonamers are from a set of aligned peptides known to bind to a given $\mathrm{MHC}$ molecule as the predictor of MHC-peptide binding. MHCII molecules bind peptides in similar yet different modes and alignments of $\mathrm{MHCll}$-ligands were obtained to be consistent with the binding mode of the peptides to their MHC class, this means the increase in affinity of $\mathrm{MHC}$ binding peptides may result in enhancement of immunogenicity of viral coat protein. These predicted of coat protein antigenic

peptides to MHC class molecules are important in vaccine development from Coxsackie B virus.

\section{References}

[1]. Flint et. al. (2000) Principles of Virology 420-2, 664-83.

[2]. Fields Bernard N., David M. Knipe, Robert M. Chanock, Joseph L. Melnick, Bernard Roizman, Robert E. Shope (1985) Fields Virology. New York: Raven Press 739-794.

[3]. Kaplan M. H., Klein S. W., McPhee J., Harper R. G. (1983) Reviews of Infectious Diseases 5 (6): 1019-1032.

[4]. Gomase V.S. and Kale K.V. (2007) National Symposium on Genomics, Proteomics and Bioinformatics, Osmanabad, India.

[5]. Gomase V. S., Kale K.V., Jyotiraj A. and Vasanthi R. (2007) Medicinal Chemistry Research, 15(1/6), 160.

[6]. Gomase V.S., Kale K.V., Shyamkumar K. and Shankar S. (2008) ICETET 2008, IEEE Computer Society in IEEE Xplore, Los Alamitos, California, 629-634.

[7]. Reche P.A., Glutting J.P. and Reinherz E.L. (2002) Hum Immunol., 63(9), 701-709.

[8]. Buus S., Lauemøller S.L., Worning P., Kesmir C., Frimurer T., Corbet S., Fomsgaard A., Hilden J., Holm A., Brunak S. (2003) Tissue Antigens, 62 (5), 378-384.

[9]. Nielsen M., Lundegaard C., Worning P., Lauemøller S.L., Lamberth K., Buus S., Brunak S., Lund O. (2003) Protein Sci., 12 (5), 1007-1017.

[10]. Bhasin M. and Raghava G.P. (2005) Nucleic Acids Res., 33, W202-207.

[11]. Gomase V. S., Tandale J.P., Patil S. A. and Kale K.V. (2006) 14th International Conference on Advance Computing \& Communication, ADCOMO6, Published by IEEE Computer Society in IEEE Xplore USA, 614-615.

[12]. Gomase V.S., Kale K.V., Chikhale N.J., Changbhale S.S. (2007) Curr. Drug Discov. Technol., 4(2), 117-1215.

[13]. Gomase V.S., Waghmare S.B., Jadhav B.V., Kale K.V. (2009) Gene Therapy and Molecular Biology, 13, 11-15. 
TABLE 1- MHC ligands from whose C-terminal end are proteosomal cleavage sites

\begin{tabular}{|l|l|l|l|l|l|l|l|}
\hline MHC-I & POS. & N & Sequence & C & MW (Da) & Score & $\%$ OPT. \\
\hline 9mer_H2_Db & 208 & YGI & NTLNNMGTL & YAR & 959.06 & 21.2 & $42.09 \%$ \\
\hline 9mer_H2_Db & 20 & TVG & TGPTNSEAI & PAL & 870.91 & 14.524 & $28.84 \%$ \\
\hline 9mer_H2_Dd & 20 & TVG & TGPTNSEAI & PAL & 870.91 & 17.522 & $41.70 \%$ \\
\hline 9mer_H2_Dd & 202 & FSR & NGVYGINTL & NNM & 932.03 & 13.041 & $31.04 \%$ \\
\hline 9mer_H2_Dd & 174 & EGN & APPRMSVPF & LSI & 983.21 & 12.735 & $30.31 \%$ \\
\hline 9mer_H2_Kb & 202 & FSR & NGVYGINTL & NNM & 932.03 & 14.51 & $32.64 \%$ \\
\hline 9mer_H2_Kb & 184 & PFL & SIGNAYSNF & YDG & 954.01 & 14.286 & $32.14 \%$ \\
\hline 9mer_H2_Kd & 142 & HQI & MYVPPGGPV & PDK & 898.09 & 14.834 & $36.32 \%$ \\
\hline 9mer_H2_Kd & 235 & TIR & IYFKPKHVK & AWI & 1141.42 & 14.212 & $34.79 \%$ \\
\hline 9mer_H2_Kd & 66 & TIE & NFLCRSACV & YFT & 994.2 & 13.742 & $33.64 \%$ \\
\hline 9mer_H2_Kk & 60 & HSR & SESTIENFL & CRS & 1021.1 & 18.178 & $34.64 \%$ \\
\hline 9mer_H2_Kk & 3 & GP & VEDAITAAI & GRV & 884.0 & 16.352 & $31.16 \%$ \\
\hline 9mer_H2_Kk & 133 & QNQ & DAQILTHQI & MYV & 1020.15 & 13.273 & $25.30 \%$ \\
\hline 9mer_H2_Kk & 79 & FTE & YENSGAKRY & AEW & 1069.15 & 12.929 & $24.64 \%$ \\
\hline
\end{tabular}

TABLE 2- MHC class II binding peptide nonamers from coat protein

\begin{tabular}{|l|l|l|l|l|}
\hline $\begin{array}{l}\text { MHC } \\
\text { ALLELE }\end{array}$ & Rank & Sequence & $\begin{array}{l}\text { Residue } \\
\text { No. }\end{array}$ & $\begin{array}{l}\text { Peptide } \\
\text { Score }\end{array}$ \\
\hline I-Ab & 1 & LTAAETGHT & 31 & 0.969 \\
\hline I-Ab & 2 & RIYFKPKHV & 234 & 0.868 \\
\hline I-Ab & 3 & RKLEFFTYV & 102 & 0.856 \\
\hline I-Ab & 4 & YAEWVITPR & 87 & 0.832 \\
\hline I-Ad & 1 & ENFLCRSAC & 65 & 0.570 \\
\hline I-Ad & 2 & VADTVGTGP & 14 & 0.522 \\
\hline I-Ad & 3 & YAEWVITPR & 87 & 0.508 \\
\hline I-Ad & 4 & TAAIGRVAD & 8 & 0.470 \\
\hline I-Ag7 & 1 & YVPPGGPVP & 143 & 1.563 \\
\hline I-Ag7 & 2 & TNSEAIPAL & 23 & 1.540 \\
\hline I-Ag7 & 3 & SIGNAYSNF & 184 & 1.444 \\
\hline I-Ag7 & 4 & EGNAPPRMS & 171 & 1.443 \\
\hline RT1.B & 1 & TTTRQSITT & 269 & 1.438 \\
\hline RT1.B & 2 & STTQNQDAQ & 127 & 1.374 \\
\hline RT1.B & 3 & TSTQQPSTT & 121 & 1.232 \\
\hline RT1.B & 4 & ITSTQQPST & 120 & 1.206 \\
\hline
\end{tabular}

